\title{
O KSZTAŁTOWANIU KOMPETENCJI GENOLOGICZNEJ W NAUCZANIU JEZZYKA POLSKIEGO JAKO OBCEGO
}

\author{
Słowa kluczowe: gatunek, kompetencja genologiczna, języki specjalistyczne
}

Streszczenie. W artykule zaprezentowano zagadnienia teoretyczne dotyczące kompetencji genologicznej jako takiej, a także w odniesieniu do nauczania języków obcych w ogóle, a zwłaszcza języka polskiego jako obcego. Przedstawiono również praktyczne aspekty związane przede wszystkim z nauczaniem odmian specjalistycznych, w obrębie których wykształciły się specyficzne gatunki.

Kształcenie polonistyczne cudzoziemców, ale także osób z doświadczeniem migracji z dnia na dzień zyskuje większy wymiar tak teoretycznej dyskusji, jak i praktycznych zastosowań. Powstaje coraz więcej opracowań naukowych, podręczników ogólnych, ale i tych o znacznym stopniu specjalizacji, zestawów ćwiczeń, kompendiów leksykalnych, gramatycznych itp. Wydawać by się mogło, że glottodydaktyka polonistyczna rozwinęła w pełni swoje skrzydła. Tymczasem są obszary, które w niewielkim stopniu poddawane są naukowej eksploracji glottodydaktycznej, choć ich znaczenie wydaje się duże. Myślę tu przede wszystkim o kształtowaniu kompetencji genologicznej uczących się języka polskiego jako obcego/drugiego. Właśnie temu zagadnieniu poświęcony zostanie niniejszy szkic, którego celem jest ukazanie wagi i roli kształtowania kompetencji genologicznej w glottodydaktyce.

\section{CZYM JEST KOMPETENCJA GENOLOGICZNA?}

Kompetencja w językoznawstwie występuje w licznych kontekstach i towarzyszą jej rozmaite dookreślenia (np. komunikacyjna, lingwistyczna). Dla Anny Duszak , ,...] kompetencja to zarówno wiedza o przedmiocie, jak i wiedza ope-

*beata.grochala@uni.lodz.pl, Uniwersytet Łódzki, Wydział Filologiczny, Instytut Filologii Polskiej i Logopedii, Zakład Lingwistyki Stosowanej i Kulturowej, ul. Pomorska 171/173, 90-236 Łódź. 
racyjna, a więc zdolność posługiwania się tą pierwszą w konkretnych sytuacjach. Dotyczy to także kompetencji językowej, która traktowana jest jako atrybut człowieka, pozwalający mu realizować różne zachowania komunikacyjne" (Duszak 1998, s. 251). Termin kompetencja obecny jest w refleksji nad dydaktyką języków obcych od dawna, co wiąże się przede wszystkim z zagadnieniem akwizycji językowej i jej uwarunkowaniami psycholingwistycznymi ${ }^{1}$. Przypomnę, że w Europejskim systemie opisu kształcenia językowego (ESOKJ) kompetencja definiowana jest jako „całość wiedzy deklaratywnej, sprawność i umiejętności oraz cechy charakteru danej osoby, które te czynniki determinują" (ESOKJ 2003, s. 20). Dzieli się ona na kompetencje ogólne oraz językowe, czyli te „pozwalające uczestnikowi życia społecznego działać za pomocą środków językowych" (ESOKJ 2003, s. 20). W ich obrębie wyróżniono trzy składniki: lingwistyczny, socjolingwistyczny i pragmatyczny. Nie zgłębiając szczegółowego opisu powyższych elementów, nadmienię jedynie, że kompetencja lingwistyczna koncentruje się wokół wiedzy systemowej o języku (fonologicznej, morfologicznej, składniowej, leksykalnej i semantycznej), socjolingwistyczna odnosi się do socjokulturowych uwarunkowań komunikacji, takich jak etykieta, zróżnicowanie stylistyczne, regionalne itp., zaś pragmatyczna obejmuje funkcjonalne wykorzystanie środków językowych, w tym, co istotne dla poczynionych tu rozważań, scenariuszy standardowych rozmów i negocjacji oraz rozpoznanie rodzaju i formy tekstu (ESOKJ 2003, s. 23-24). W szczegółowym opisie kompetencji pragmatycznej autorzy ESOKJ wskazali na kompetencję dyskursywną związaną z organizowaniem, budową i układem przekazu językowego, kompetencję funkcjonalną polegającą na wypełnianiu określonej funkcji, wreszcie na znajomość schematów interakcyjnych (ESOKJ 2003, s. 109). Wydawać by się mogło, że kompetencja genologiczna jest tożsama z kompetencją dyskursywną, jednak uszczegółowiony opis w ESOKJ wskazuje na takie elementy jak układ zdań według określonego porządku strukturalnego i semantycznego, zachowanie kohezji i koherencji, przestrzeganie maksym konwersacyjnych itp. Mamy zatem do czynienia z podejściem tekstologicznym - ważnym i cennym - jednak moim zdaniem niewystarczającym, a jego uzupełnienie o element genologiczny wydaje się kwestią bezdyskusyjną. Co zatem kryłoby się pod pojęciem kompetencji genologicznej? Termin ten występuje w literaturze poświęconej gatunkom tekstu, choć przybiera różne nazwy. I tak Michał Głowiński (1987), Igor Borkowski (1999), Mieczysław Balowski (2000), Grzegorz Grochowski (2001), Monika Zaśko-Zielińska (2002) oraz Maria Wojtak $(2009 b, 2016)$ mówią o świadomości gatunkowej, Mateusz Kasiak (2015) o świadomości genologicznej, Halina Grzmil-Tylutki (2007) i Janina Fras (2013) o kompetencji generycznej, zaś Magdalena Ślawska (2019) o kompeten-

${ }^{1}$ Ida Kurcz zwraca uwagę, że kompetencja językowa to element, część szerszej wiedzy, na którą składa się również kompetencja komunikacyjna, czyli umiejętność użycia języka adekwatnie do intencji nadawcy oraz odpowiednio do sytuacji i wiedzy o odbiorcy (Kurcz 1987, s. 69). Koncepcja ta znajduje swoje odwzorowanie także w stosunku do kompetencji genologicznej. 
cji gatunkowej. Wspomniane wyżej terminy często stosowane są synonimicznie przez tych samych autorów. I tak świadomość gatunkowa traktowana jest przez badaczy ,analogicznie do innych rodzajów świadomości (językowej, komunikacyjnej, stylistycznej)" (Wojtak 2009b, s. 21) jako wiedza i zbiór umiejętności, a kompetencja gatunkowa to: ,wiedza o gatunkach, znajomość wzorców konkretnych gatunków, umiejętność stosownej dyskursywnej realizacji wzorców" (Wojtak 2009b, s. 21). Tak zdefiniowana kompetencja gatunkowa czy też genologiczna znajduje swoje zastosowanie w glottodydaktyce. Dla porządku wywodu dodam, że rezygnuję z określenia świadomość na rzecz kompetencji, aby z jednej strony nawiązać do ESOKJ, z drugiej zaś wyraźnie wskazać nie tylko na znajomość gatunków, ich percepcję, ale przede wszystkim na produkcję². Kolejny problem nazewniczy łączy się z określeniami gatunkowa/generyczna/genologiczna, które ponownie używane są synonimicznie - tym razem zdecydowałam się na określenie genologiczna ze względu na bardziej uniwersalny (internacjonalny) charakter tego przymiotnika. Niezależnie od tego, na jaką nazwę się zdecydujemy, istotę stanowi znajomość i umiejętność konstruowania gatunków. O samym gatunku i jego implikacjach glottodydaktycznych pisała Anna Dunin-Dudkowska (2018). Artykuł ów stanowi bardzo istotny wkład w propagowanie wątków genologicznych w dydaktyce języka polskiego jako obcego. Autorka przedstawiła w nim w syntetyczny sposób różne rozumienia pojęcia gatunek, koncentrując się na koncepcji wzorca gatunkowego Marii Wojtak i pokazując możliwość jej wykorzystania w nauczaniu języka polskiego jako obcego/drugiego. Niniejszy tekst rości sobie prawo do uzupełnienia wspomnianego, bardzo ważnego tekstu Dunin-Dudkowskiej, do pójścia o krok dalej - w kierunku postulowanej kompetencji genologicznej.

W literaturze odnaleźć można liczne definicje gatunku mowy. Wspomnę choćby o prekursorskich ustaleniach Michaiła Bachtina, który za gatunek mowy uznaje „konkretne, względnie trwałe pod względem tematycznym, kompozycyjnym i stylistycznym typy wypowiedzi" (Bachtin 1986, s. 354). Z kolei Aleksander Wilkoń definiuje gatunek jako ,typ tekstów blisko spokrewnionych, mających tę samą (lub podobną) funkcję, dystrybucję semantyczną i formalną określonych cech językowych oraz związek z kulturą i pragmatyką komunikacji danej wspólnoty etnicznej" (Wilkoń 2002, s. 200). Bożena Witosz zwraca uwagę na związki i rozbieżności między tekstem, stylem a gatunkiem. Podkreśla, że „kategorię gatunku buduje sieć parametrów wzajemnie się warunkujących, obejmujących plan kognitywny, funkcjonalny, sytuacyjno-interakcyjny, strukturalny, aksjologiczny oraz intertekstualny” (Witosz 2005, s. 109). Dla Marii Wojtak gatunek to „zbiór abstrakcyjny (model, wzorzec) mający jednak różnorodne konkretne realizacje w formie wypowiedzi [...], zbiór konwencji, które podpowiadają członkom okre-

${ }^{2}$ Por. definicje słownikowe obu pojęć: świadomość ‘wiedza o czymś, uświadamianie sobie czegoś, zdawanie sobie sprawy z czegoś’; kompetencja ‘zakres czyjejś wiedzy, umiejętności’ (USJP 2003). 
ślonej wspólnoty komunikatywnej, jaki kształt nadać konkretnym interakcjom" (Wojtak 2004, s. 16). Dla poczynionych dalej rozważań pomocna jest definicja operacyjna gatunku, który za M. Ślawską definiuję jako „sposób wykonania działania komunikacyjnego, które zależy od poziomu kompetencji, świadomości gatunkowej nadawcy" (Ślawska 2019, s. 38). Nacisk położony jest zatem na produkcję poszczególnych gatunków. Co ważne, kompetencja genologiczna, zgodnie z koncepcją gatunku M. Wojtak, łączyłaby się z umiejętnością przekładania schematu abstrakcyjnego na konkretny tekst, wyrażającą się w znajomości wzorca, ale także w jego dyskursywnym zakorzenieniu (por. Ślawska 2019, s. 37). Jak pisze A. Dunin-Dudkowska: „Opis wszystkich aspektów opisu wzorca gatunkowego (strukturalnego, pragmatycznego, semantycznego oraz stylistycznego) może stanowić podstawę do efektywnego nauczania zarówno czynnej, jak i biernej znajomości poszczególnych odmian gatunkowych rodzimych użytkowników języka. Praktyczne zastosowanie takiego opisu w dydaktyce jest jednocześnie logiczną konsekwencją kontrastywnych badań językowych i genologicznych, dostarczających narzędzi do nauczania języka obcego na różnych poziomach kompetencji językowej, w zależności od stopnia trudności gatunku i frekwencji jego stosowania" (Dunin-Dudkowska 2018, s. 117).

\section{KOMPETENCJA GENOLOGICZNA A NORMA}

Ważnym zagadnieniem jest relacja między kompetencją genologiczną a normą. Podejście normatywne do gatunku obecne jest w refleksji językoznawczej, ale nie poświęca się tu zbytniej uwagi aspektowi glottodydaktycznemu. W badaniach normatywistycznych wprowadza się pojęcie normy gatunkowej, która rozumiana jest rozmaicie, w zależności od tego jak definiuje się sam gatunek. Jeśli bowiem przyjąć, że gatunek to wzór, to wówczas sam w sobie staje się normą. Ciekawie zagadnienie to prezentuje M. Zaśko-Zielińska, która uważa, że „celem normy gatunkowej jest nie tyle wskazanie tego, co poprawne i błędne, ile możliwie całościowe zaprezentowanie sytuacji komunikacyjnej, z jaką związany jest gatunek, gdyż świadomość językowa sprzyja poprawności wypowiedzi. Wśród obowiązujących kryteriów poprawności językowej najważniejsze dla normy gatunkowej wydaje się kryterium uzualne" (Zaśko-Zielińska 2002, s. 34). W ten sposób poprawne użycie gatunku ściśle łączy się z sytuacją komunikacyjną. Przekładając to stwierdzenie na dydaktykę języków obcych, należałoby uznać, że w obrębie kompetencji genologicznej poza percepcją i tworzeniem gatunków istotne jest również ich adekwatne do sytuacji zastosowanie. W tym miejscu należy wspomnieć o aspekcie kulturowym, z którym łączy się pojęcie gatunku. Pisał o tym M. Bachtin, który twierdził, że „odlewamy naszą mowę w formy określonych gatunków [...]. Te 
formy dane są nam tak, jak dany jest język ojczysty" (Bachtin 1979, s. 25; cyt. za Wierzbicka 1999, s. 228), a także Stanisław Gajda, zdaniem którego w teorii gatunku należy mocno wyeksponować „komunikacyjno-kulturowego kontekstu wypowiedzi" (Gajda 1982, s. 259). A zatem skoro nauczamy języka jako obcego w opozycji do języka ojczystego, to i w takiej opozycji warto spojrzeć na gatunki. Jak pokazała bowiem Anna Wierzbicka, dana kultura może być badana przez pryzmat charakterystycznych dla niej gatunków (Wierzbicka 1999, s. 228). Badaczka zaprezentowała liczne gatunki „nieprzekładalne” na inne języki ze względu na ich kulturowe uwarunkowania - wspomnę choćby o polskim podaniu czy kawale (por. Wierzbicka 1999). Co więcej, każdy język, a właściwie każda kultura wytwarza swoje warianty gatunków, które można by uznać za uniwersalne, jak chociażby życiorys czy list motywacyjny, który to gatunek z perspektywy glottodydaktycznej analizuje w niniejszym tomie A. Dunin-Dudkowska (2019). W innym tekście lubelska badaczka podkreśla, że: „Ważne jest pokazanie pragmatyki gatunku, zależnej od potrzeb kulturowych danego społeczeństwa oraz jego językowego obrazu świata i systemu aksjologicznego. Wyniki studiów i analiz komparatystycznych powinny być wykorzystane $\mathrm{w}$ celu zidentyfikowania różnic między analogicznymi gatunkami w omawianych kulturach (na wszystkich poziomach opisu wzorca) dla wskazania cudzoziemcom miejsc grożących wystąpieniem transferu negatywnego. W glottodydaktyce należałoby skoncentrować się na nauczaniu praktycznych wzorców gatunkowych stosowanych w komunikacji nieprofesjonalnej, z włączeniem wzorców gatunkowych komunikacji profesjonalnej w kształceniu różnych grup zawodowych (np. prawników, ekonomistów, itd.) i tłumaczy" (Dunin-Dudkowska 2018, s. 117). Uczący się języka obcego (nie tylko polskiego) często stają przed dysonansem poznawczym, kiedy gatunki o podobnej nazwie mają zupełnie inną strukturę, cel, słowem odmienne wzorce gatunkowe w każdym z czterech aspektów, a łączy je jedynie nazwa, jak np. ma to miejsce w przypadku polskiego eseju $^{3} \mathrm{w}$ opozycji do eseju przynależnego kulturze anglosaskiej ${ }^{4}$.

${ }^{3}$ Esej - dość obszerny utwór, swobodnie rozwijający, interpretujący jakieś zjawisko (zwłaszcza intelektualne) lub dociekający problemu, eksponujący przy tym podmiotowy punkt widzenia oraz dbający o oryginalny, artystyczny sposób przekazu. Cechą charakterystyczną eseju jest eksponowanie przez osobę mówiącą swego punktu widzenia. Obok - mniej ważnych - związków logicznych, występują w eseju nieskrępowane rygorami naukowymi skojarzenia pomysłów, a obok zdań weryfikowalnych - poetyckie obrazy, zaskakujące swoją treścią sformułowania, zawierające myśli skłócone z powszechnie żywionymi przekonaniami (paradoksy), błyskotliwe aforyzmy oraz narracja liryczno-refleksyjna (Stownik terminologii... 2006).

${ }^{4}$ A typical essay contains many different kinds of information, often located in specialized parts or sections. Even short essays perform several different operations: introducing the argument, analyzing data, raising counterarguments, concluding. Introductions and conclusions have fixed places, but other parts don’t. (Typowy esej zawiera wiele różnych rodzajów informacji, często zlokalizowanych w specjalistycznych częściach lub sekcjach. Nawet na krótkie eseje składa się kilka różnych operacji: wprowadzenie argumentu, analizowanie danych, podnoszenie kontrargumentów, wysnuwanie wniosków. Wstęp i konkluzja mają ustalone miejsce, a pozostałe części nie. [tłum. BG]) - https://writingcenter.fas.harvard.edu [28.08.2019]. 


\section{KOMPETENCJA GENOLOGICZNA W PRAKTYCE GLOTTODYDAKTYCZNEJ}

Wspominana już A. Dunin-Dudkowska (2018) poddała analizie kilka podręczników ogólnych do nauczania języka polskiego jako obcego w poszukiwaniu sposobów prezentacji gatunków i ich wzorców. Nie wiemy, czy wybór był celowy, ale w analizowanych pomocach dydaktycznych A. Dunin-Dudkowska odnalazła elementy opisu gatunkowego, a tym samym kształcenia kompetencji genologicznej. Wzmianki bądź bardziej szczegółowe opisy dotyczyły gatunków ujętych w programach nauczania języka polskiego jako obcego (Programy nauczania... 2016) oraz standardach egzaminacyjnych (por. Rozporzadzenie MNiSW ... 2016). Na potrzeby niniejszego szkicu przeprowadzono własną, skróconą analizę wybranych podręczników specjalistycznych przeznaczonych do nauczania odmian zawodowych polszczyzny. Wydawać by się mogło, że pomoce adresowane najczęściej do osób przygotowujących się do podjęcia studiów na danym kierunku albo już studiujących powinny przedstawiać wzorce gatunkowe i sposoby ich realizacji właściwe dla określonej profesji. I tak np. w podręczniku dla adeptów architektury spodziewałabym się informacji o takich gatunkach jak projekt architektoniczny, dziennik budowy, pozwolenie na budowę itp. Wszystkie te formy łączą się ściśle z pracą architekta, jednocześnie zaś są mocno uwarunkowane kulturowo, a dokładniej - prawnie. Ich kształt określa bowiem polskie Prawo budowlane (dziennik budowy - art. 45 ust. 1, projekt budowlano-architektoniczny - art. 34 ust. 3). Od specjalisty w zakresie architektury czy budownictwa wymagać należy tak umiejętności czytania, jak i tworzenia (wypełniania) owych dokumentów. Idąc tym tropem - od podręcznika należałoby wymagać wprowadzenia nie tylko specjalistycznego słownictwa, ale i specjalistycznych gatunków. Niestety, tak się nie dzieje, a zatem kompetencja genologiczna (tu można by mówić o specjalistycznej kompetencji genologicznej) nie jest kształtowana - jak choćby w podręczniku Edyty Gałat (2017) Architektura - język specjalistyczny. Podobnie w książce stanowiącej wprowadzenie do języka biznesu pt. O biznesie po polsku autorstwa Marzeny Kowalskiej (2018). Co prawda odnajdziemy w nim kwestionariusz osobowy (a właściwie miejsca do uzupełnienia danymi, nie zachowano bowiem struktury architektonicznej gatunku) oraz $\mathrm{CV}$, ale brakuje wielu innych elementów, które mogłyby wspierać rozwój kompetencji gatunkowej. I tak w rozdziale poświęconym zakładaniu konta w banku można by zaprezentować formularz, którego wypełnienie jest konieczne przy wykonywaniu tej czynności, a w części poświęconej opisowi sytuacji finansowej firmy - konkretne raporty finansowe. Analogicznie w podręcznikach do języka medycznego powinien się znaleźć wzór skierowania, recepty czy zwolnienia lekarskiego, a tych w analizowanych pozycjach nie ma (por. T. Jurek, Proszę mi powiedzieć, co się stato (2007); M. Janowska, Ś. Sikor- 
ska, Proszę oddychać (2007, 2015). Chlubny wyjątek stanowi książka Magdaleny Ławnickiej-Borońskiej Język polski w medycynie. A Guide to Polish in Medical Practice (2013), w której zamieszczono obszerny aneks zawierający bogatą dokumentacje medyczną, a tym samym wzory wielu gatunków, jak np. skierowanie, zlecenie badania, karta informacyjna pacjenta). Ten skrócony przegląd podręczników specjalistycznych pokazuje, że kompetencja genologiczna nie jest w nich należycie kształtowana. Tymczasem praktyka pokazuje, że gatunki, zwłaszcza te skonwencjonalizowane, nie są w polskiej kulturze elementem łatwym tak w percepcji, jak i w produkcji. Obwarowania prawne, skomplikowana struktura i często niezrozumiały język urzędowy sprawiają, że cudzoziemiec nieprzygotowany do kontaktu z takimi tekstami, nawet o dużej kompetencji językowej, może napotkać na problemy $\mathrm{w}$ obcowaniu ze wspomnianymi gatunkami ${ }^{5}$ (podobnie jak wielokrotnie ma to miejsce w przypadku rodzimych użytkowników polszczyzny, dla których rozmaite gatunki urzędowe lub techniczne są nieczytelne ${ }^{6}$ ).

Odrębny problem stanowi kształtowanie kompetencji genologicznej osób $z$ doświadczeniem migracji, które rozpoczynają naukę w polskim systemie oświatowym. Rozbieżność między „mapami genologicznymi” uwarunkowanymi kulturowo jest bowiem ogromna. Za przykład niech posłuży wspomniany już wyżej esej, któremu w kulturze polskiej odpowiada częściowo rozprawka, częściowo wypracowanie, częściowo referat, jednak żadnego z tych gatunków nie można z esejem utożsamiać.

\section{KONKLUZJA}

Magdalena Ławnicka-Borońska oraz Kamila Kubacka (2016) twierdzą, że rdzeń kursu specjalistycznego stanowi słownictwo danego rejestru języka, dlatego podręczniki koncentrują się na warstwie leksykalnej. Z kolei A. Dunin-Dudkowska zauważa, że: „Na podstawie realizacji wzorca gatunkowego można także zdiagnozować kompetencję komunikacyjną uczących się (ocena znajomości wzorca i sposobu realizacji jego poszczególnych aspektów). Nauczanie wzorca gatunkowego pomaga opanować strukturę wypowiedzi, specjalistyczną leksykę, typową dla stylu danego gatunku, charakterystyczną składnię oraz inne cechy stylu gatunku" (Dunin-Dudkowska 2018, s. 117). Wydaje się, że połączeniem obu postulatów byłoby wprowadzenie w zakres kształcenia specjalistycznego

${ }^{5} \mathrm{O}$ analogicznych problemach związanych z tekstami urzędowymi pisała I. Dembowska-Wosik (2015).

${ }^{6}$ Skomplikowana struktura i język tekstów urzędowych stanowią m.in. przedmiot badań w Pracowni Prostej Polszczyzny działającej na Uniwersytecie Wrocławskim: www.ppp.uni.wroc.pl [28.08.2019]. 
także elementów budowania specjalistycznej kompetencji genologicznej. Dzięki temu uczący się poznawaliby leksykę, a jednocześnie przyswajali i tworzyli teksty w obrębie gatunków typowych dla danej odmiany.

Kompetencja genologiczna winna jednak być rozwijana także na kursach ogólnych i to na każdym poziomie, bowiem nawet najprostsze akty mowy stanowią realizację wzorca. Być może w przyszłości można by opracować podręcznik(i) do kształcenia omawianej kompetencji, które z wykorzystaniem koncepcji M. Wojtak prezentowałyby strukturę gatunku wraz z uwarunkowaniami stylistycznymi i pragmatycznymi, a także jego konkretne, najlepiej autentyczne realizacje. Docelowo zaś prowadziłyby uczących się do stworzenia własnego tekstu uwzględniającego założenia wzorca gatunkowego. Skoro, jak pisze Stanisław Gajda, ,gatunek tekstu uznaje się za naturalną i uniwersalną kategorię rzeczywistości komunikacyjnej, za ważny mechanizm sterujący ludzkimi zachowaniami komunikacyjnymi, to konsekwencją jest uznanie go za istotne pojęcie wyjaśniająco-interpretatywne w stosunku do tych zachowań" (Gajda 2009, s. 144), to przy poznawaniu świata polszczyzny oczami cudzoziemców kształcenie kompetencji genologicznej wydaje się nieodzowne.

\section{BIBLIOGRAFIA}

Bachtin M., 1986, Estetyka twórczości słownej, Warszawa.

Balowski M., 2000, Świadomość gatunkowa a wzorzec normatywny (na przykładzie gatunków prasowych), w: D. Ostaszewska (red.), Gatunki mowy i ich ewolucja. T. 1: Mowy piękno wielorakie, Katowice, s. 225-237.

Borkowski I., 1999, Hasło wyborcze - gatunek mowy i jego funkcja w świadomości użytkowników polszczyzny (na materiale ankietowym), w: J. Miodek (red.), współudział M. Zaśko-Zielińska,

I. Borkowski, Mowa rozświetlona myśla. Świadomość normatywno-stylistyczna wspótczesnych Polaków, Wrocław, s. 269-282.

Dembowska-Wosik I., 2015, Słownictwo stylu urzędowego a język polski jako drugi (pilotażowe badanie korpusowe), w: I. A. Ndiaye, S. Przybyszewski, M. Rółkowska (red.), Język polski - nie taki obcy, Olsztyn, s. 43-53.

Dunin-Dudkowska A., 2018, Gatunki wypowiedzi w kontekście glottodydaktycznym, „Acta Universitatis Lodziensis. Kształcenie Polonistyczne Cudzoziemców”, t. 25, B. Grochala, I. Dembowska-Wosik (red.), s. 111-122.

Dunin-Dudkowska A., 2019, The Cover Letter as a Genre of Speech in Teaching Polish as a Foreign Language, „Acta Universitatis Lodziensis. Kształcenie Polonistyczne Cudzoziemców”, t. 26, G. Zarzycka, B. Grochala, I. Dembowska-Wosik (red.).

Duszak A., 1998, Tekst, dyskurs, komunikacja międzykulturowa, Warszawa.

Europejski system opisu kształcenia językowego: uczenie się, nauczania, ocenianie (ESOKJ), 2003, Warszawa.

Fras J., 2013, O typologii wypowiedzi medialnych i dziennikarskich, Wrocław.

Gajda S., 1982, Podstawy badań stylistycznych nad językiem naukowym, Wrocław.

Gajda S., 2009, Gatunki wypowiedzi i genologia, w: Z. Bilut-Homplewicz, W. Czachur, M. Smykała (red.). Lingwistyka tekstu w Polsce i Niemczech: pojęcia, problemy, perspektywy, Wrocław, s. $135-146$. 
Gałat E., 2017, Architektura - język specjalistyczny. Skrypt dla obcokrajowców na poziomie $A 2+/ B 1$, Kraków.

Głowiński M., 1987, Gatunek literacki i problemy poetyki historycznej, w: H. Markiewicz(red.), Problemy teorii literatury, Wrocław, s. 123-143.

Grochowski G., 2001, Pośmiertny tryumf genologii, „Teksty Drugie”, nr 5, s. 100-110.

Grzmil-Tylutki H., 2007, Gatunek w świetle francuskiej teorii dyskursu, Kraków.

Janowska M., Sikorska Ś., 2007, Proszę oddychać. Materiały do nauczania medycznego języka polskiego. Część I i II, Warszawa.

Janowska M., Sikorska Ś., 2015, Proszę oddychać. Materiały do nauczania medycznego języka polskiego. Część III, Warszawa.

Jurek T., 2007, Proszę mi powiedzieć, co się stało?, Poznań.

Kasiak M., 2015, Artykut publicystyczny w świadomości genologicznej dziennikarzy prasowych, „Studia Medioznawcze”, nr 4(63), s. 83-94.

Kowalska M., 2018, O biznesie po polsku. Wprowadzenie do języka biznesu. Podręcznik do nauki języka polskiego (B1, B2), Kraków.

Kurcz I., 1987, Język a reprezentacja świata w umyśle, Warszawa.

Ławnicka-Borońska M., 2013, Język polski w medycynie. A Guide to Polish in Medical Practice, Warszawa.

Ławnicka-Borońska M., Kubacka K., 2016, Język polski medyczny w wybranych materiałach dydaktycznych ostatniego ćwierćwiecza, „Acta Universitatis Lodziensis. Kształcenie Polonistyczne Cudzoziemców”, t. 23, G. Zarzycka, M. Biernacka (red.), s. 215-235.

Programy nauczania języka polskiego jako obcego. Poziomy A1-C2, 2016, I. Janowska, E. Lipińska, A. Rabiej, A. Seretny, P. Turek (red.), Kraków.

Rozporządzenie Ministra Nauki i Szkolnictwa Wyższego z dnia 26 lutego 2016 r. w sprawie egzaminów z języka polskiego jako obcego, Dz.U. 2016, poz. 405.

Słownik terminologii medialnej, 2006, W. Pisarek (red.), Kraków.

Ślawska M., 2019, Sztuka mediów. O świadomości gatunkowej dziennikarzy prasowych, Katowice.

Uniwersalny słownik języka polskiego (USJP), 2003, S. Dubisz (red.), Warszawa.

Wierzbicka A., 1999, Język - umyst - kultura, Warszawa.

Wilkoń A., 2002, Spójność i struktura tekstu, Kraków.

Witosz B., 2005, Genologia lingwistyczna. Zarys problematyki, Katowice.

Wojtak M., 2004, Gatunki prasowe, Lublin.

Wojtak M., 2009, Wzorce zachowań językowych a praktyka komunikacyjna, w: A. Piotrowicz, K. Skibski, M. Szczyszka (red.), Kształtowanie się wzorów $i$ wzorców językowych, Poznań.

Wojtak M., 2016, Zmienność w jedności, czyli o gatunkach prasowych i ich metamorfozach, w: G. Filip (red.), Problemy i nadzieje współczesnego dziennikarstwa, Rzeszów, s. 103-128.

Zaśko-Zielińska M., 2002, Przez okno świadomości. Gatunki mowy w świadomości użytkowników języka. Wrocław.

\section{Beata Grochala}

\section{GENRE COMPETENCE IN TEACHING POLISH AS A FOREIGN LANGUAGE}

Keywords: genre, genre competence, languages for specific purposes

Abstract. The article presents theoretical issues related generally to the genre competence, but also specifically to foreign language pedagogy and in particular to teaching Polish as a foreign language. The author presents practical aspects related to the teaching of foreign languages for specific purposes, which must include the genres specific to the variety of language being taught. 